\title{
Levels of soluble E-selectin in patients with active Behçet's disease
}

\author{
Refik Ali Sari • Ahmet Kiziltunç • Seyithan Taysi • \\ Serpil Akdemir • Mehmet Gündoğdu
}

Published online: 17 February 2007

(C) Clinical Rheumatology 2007

\section{Clin Rheumatol (2005) 24:55-59}

The surname of the third author is Taysi, not Taysy.

The surname of the fourth author is Akdemir, not Akdemýr.

The online version of the original article can be found at http://dx.doi. org/10.1007/s10067-004-0982-8.

R. A. Sari $(\bowtie)$

Department of Immunology/Rheumatology,

Atatürk University Medical School,

25240 Erzurum, Turkey

e-mail: refikali@yahoo.com

A. Kiziltunç $\cdot$ S. Taysi

Department of Biochemistry, Atatürk University Medical School,

25240 Erzurum, Turkey

S. Akdemir • M. Gündoğdu

Department of Internal Medicine,

Atatürk University Medical School,

25240 Erzurum, Turkey 